\title{
Hubungan Batu Saluran Kemih Bagian Atas dengan Karsinoma Sel Ginjal dan Karsinoma Sel Transisional Pelvis Renalis
}

\author{
Romi Saputra ${ }^{1}$, Alvarino ${ }^{2}$, Hafni Bachtiar ${ }^{3}$
}

\begin{abstract}
Abstrak
Insiden karsinoma sel ginjal dan karsinoma sel transisional pelvis renalis sebagai jenis histopatologis terbanyak pada keganasan ginjal menunjukkan trend peningkatan insiden di seluruh dunia. Batu saluran kemih menunjukkan trend peningkatan insiden yang serupa. Hal ini memungkinkan adanya hubungan. Penelitian sebelumnya mendapatkan hasil yang kontroversial. Tujuan penelitian ini adalah melihat hubungan antara batu saluran kemih bagian atas dengan karsinoma sel ginjal dan karsinoma sel transisional pelvis renalis di RSUP Dr. M Djamil padang dan RSAM Bukittinggi. Penelitian ini menggunakan desain case control study pada rekam medis yang dilakukan pada bulan September hingga Desember 2018. Didapatkan 34 sampel dengan hasil histopatologi karsinoma sel ginjal dengan rasio jenis kelamin 1:1,3. Sampel terbanyak adalah kelompok umur 50-59 tahun (26,47\%), mean: 52,8 $\pm 13,79$. Didapatkan 15 sampel karsinoma sel transisional pelvis renalis dengan rasio jenis kelamin 2,75:1. Sampel terbanyak

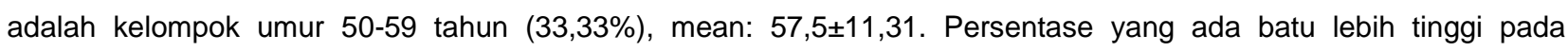
karsinoma sel ginjal dibandingkan dengan yang tidak karsinoma sel ginjal yaitu $62,5 \%: 23,1 \%$. Secara statistik perbedaan tersebut tidak bermakna $(P>0,05)$. Peluang untuk timbulnya karsinoma sel ginjal sebesar 5,6 kali pada yang ada batu dibandingkan dengan yang tidak ada. Persentase yang ada batu lebih tinggi pada karsinoma sel transisional pelvis renalis dibandingkan dengan yang tidak karsinoma sel transisional pelvis renalis yaitu $71,4 \%: 25 \%$. Secara statistik perbedaan tersebut tidak bermakna $(P>0,05)$. Peluang unuk timbulnya karsinoma sel transisional pelvis renalis sebesar 7,5 kali pada yang ada batu dibandingkan dengan yang tidak ada.
\end{abstract}

Kata Kunci: batu saluran kemih, karsinoma sel ginjal, karsinoma sel transisional

\begin{abstract}
The incidence of renal cell carcinoma and renal pelvic cell carcinoma as the most histopathological type in renal cancer shows an increasing trend of incidents throughout the world. Urinary calculi show a trend of increasing of similar incidents. This allows a connection between them. Previous research has had controversial results. The objective of this study was to see the relationship between upper urinary calculi and renal cell carcinoma and renal pelvic cell carcinoma in Dr. M Djamil Hospital padang and Ahmad Moctar Hospital Bukittinggi. This study used a case control study design and was conducted from September to December 2018. 34 samples were obtained with histopathological results of renal cell carcinoma with a sex ratio of 1: 1.3. The largest sample is the age group 50-59 years (26.47\%), mean: $52.8 \pm 13.79$. Obtained 15 renal pelvic transitional cell carcinoma samples with sex ratio 2.75 : 1. The largest sample is the age group 50-59 years (33.33\%), mean: $57.5 \pm 11.31$. The percentage of stones is higher in renal cell carcinoma compared to non renal cell carcinoma, which is $62.5 \%: 23.1 \%$. Statistically the difference was not significant $(P>0.05)$. Opportunities for the emergence of renal cell carcinoma are 5.6 times in those with stones compared to none. The percentage of stones that is higher in renal pelvic transitional cell carcinoma compared to those without renal pelvic transitional cell carcinoma is $71.4 \%: 25 \%$. Statistically the difference was not significant $(P>$ 0.05). The opportunity for the emergence of renal pelvic transitional cell carcinoma is 7.5 times in that there is stone compared to none.
\end{abstract}

Keywords: urinary calculi, renal cell carcinoma, trantitional cell carcinoma 
Affiliasi penulis: 1. Program Pendidikan Dokter Spesialis-1 Bagian IImu Bedah Fakultas Kedokteran Universitas Andalas Padang (FK Unand), 2. Bagian Bedah FK Unand, 3. Bagian IImu kesehatan Masyarakat FK Unand

Korespondensi: Romi Saputra, Email:

romigeneralsurgeon1@gmail.com Telp: 081267611215

\section{PENDAHULUAN}

Keganasan ginjal merupakan keganasan urogenitalia terbanyak ketiga setelah keganasan prostat dan kandung kemih. Semakin meluasnya penggunaan ultrasonografi abdomen sebagai salah satu pemeriksaan penyaring di klinik rawat jalan maka semakin banyak pula ditemukan kasus keganasan ginjal yang masih dalam stadium awal. ${ }^{1}$ Ginjal terdiri atas parenkim ginjal dan sistem saluran ginjal yaitu sistem pelvikalises. Kedua bagian ginjal itu bisa terserang tumor jinak maupun tumor ganas, dengan gambaran klinik dan prognosis yang berbeda-beda. ${ }^{1}$ Keganasan ginjal yang tersering adalah karsinoma sel ginjal mencakup sekitar $85 \%$ kasus, karsinoma sel transisional sekitar $12 \%$ dan jenis lainnya $2 \%{ }^{2}$

Insidensi di Hongkong, India, Korea dan Taiwan berkisar 3,24-6,0 per 100.000 penduduk. Insidensi di Jepang adalah 5,2 per 100.000 penduduk, dengan angka kematian 1,8 per 100.000 penduduk. Insidensi di Malaysia adalah 1,9 per 100.000 penduduk. $^{2}$ Insidensi keganasan ginjal di Indonesia diperkirakan 2,4-3 kasus / 100.000 penduduk. Hasil Ini merupakan peningkatan dari perkiraan sebelumnya yaitu 1,4 -1,8 kasus /100.000 penduduk. ${ }^{3}$

Data dari dua rumah sakit tersier di Jakarta Indonesia, rumah sakit Cipto Mangunkusumo dan Pusat Kanker Dharmais tahun 1995 hingga 2007 (13 tahun) didapatkan 144 kasus karsinoma sel ginjal berjumlah 77 kasus (53,5\%). Penelitian lain yang secara khusus mencari kasus karsinoma sel ginjal di rumah sakit Cipto Mangunkusumo dari tahun 1995 hingga 2009 mendapatkan 99 kasus, yang merupakan $33 \%$ dari semua kasus keganasan pada ginjal. Penelitian ini juga mengungkapkan peningkatan kejadian 1,5 hingga 2 kali lipat untuk setiap periode 5 tahun. ${ }^{4}$

Karsinoma sel ginjal merupakan 2-3\% dari semua keganasan dengan insiden tertinggi di negaranegara Barat. Kejadian karsinoma sel ginjal meningkat sekitar $2 \%$ pada dua dekade terakhir baik di seluruh dunia maupun di Eropa. Pada tahun 2012 terdapat sekitar 84.400 kasus baru karsinoma sel ginjal dengan 34.700 kematian di Uni Eropa. Data dari Amerika Serikat juga menunjukkan peningkatan kejadian. ${ }^{5}$

Karsinoma sel transisional pelvis renalis merupakan 5-10\% dari keganasan pada ginjal dengan kejadian hampir 2 kasus per 100.000 penduduk pertahun di negara barat. Terdapat tingginya insiden karsinoma sel transisional pelvis renalis di Taiwan, terutama di bagian pantai barat daya yang mencapai $20-25 \%$ dari keganasan pada ginjal. Ada kemungkinan terdapat hubungan antara, blackfoot disease, paparan arsenik dalam air minum, aristolochic acid dan obat obatan tradisional. ${ }^{6}$ Penelitian di Victoria (negara bagian Australia) antara tahun 2001 sampai 2011 didapatkan 722 kasus baru dengan overall 5-year survival rate $32 \%{ }^{7}$ Penelitian di Rumah Sakit Kanker Dharmais Jakarta, mulai Januari 1995 sampai Desember 2009 terdapat 42 pasien karsinoma pelvis renalis dan ureter dengan lesi primer terbanyak pada pelvis renalis yakni $90,5 \%$ kasus dan jenis histopatologi terbanyak adalah karsinoma sel transisional sebesar $47,6 \%{ }^{8}$

Batu saluran kemih adalah salah satu masalah utama di bidang urologi. Insiden batu saluran kemih diperkirakan 10 - 15\% pada populasi global. ${ }^{9}$ Resiko terbentuknya batu saluran kemih pada populasi di Amerika Utara diperkirakan sebanyak 7-13\%, Eropa 5\%-9\% dan di Asia 1\%-5\%. Prevalensi batu saluran kemih di Korea Selatan juga memperlihatkan adanya peningkatan prevalensi batu saluran kemih dari 3,5\% menjadi 11,5\% antara tahun 1998 hingga 2013. Insidensi batu saluran kemih di India dan Malaysia juga mengalami peningkatan yakni kurang dari 40/100.000 penduduk pada tahun 1960an menjadi 930/100.000 penduduk dan 442,7/100.000 penduduk dalam 3 dekade kemudian. ${ }^{10}$

Batu saluran kemih merupakan penyakit urologi kedua terbanyak di Indonesia setelah infeksi saluran kemih dan penyakit terbanyak di antara penyakit penyakit yang memerlukan tindakan di bidang urologi. Insidensi dan prevalensi batu saluran kemih di Indonesia belum pasti. Penelitian di rumah sakit Arifin Ahmad Pekanbaru pada tahun 2010 hingga tahun 
2016, didapatkan 1.418 pasien dengan batu saluran kemih yang terdiri dari 951 (67,1\%) laki-laki dan 467 $(32,9 \%)$ perempuan dengan rasio $2: 1$. Jumlah pasien terbanyak pada kelompok umur 40-49 tahun sebanyak 407 orang $(28,7 \%)$, dan yang paling sedikit pada kelompok umur $<20$ tahun sebanyak 27 orang $(1,9 \%)^{11}$

Ada trend peningkatan insiden batu saluran kemih, karsinoma sel ginjal dan karsinoma sel transisional memungkinkan terdapatnya hubungan diantaranya. ${ }^{9}$ Chung et al melaporkan bahwa terdapat peningkatan resiko karsinoma sel ginjal dan karsinoma sel transisional sebanyak 2,76 dan 3.96 kali pada pasien dengan riwayat batu ginjal. ${ }^{12}$ Zengin et al melaporkan, dari 97 pasien yang dilakukan dilakukan nefrektomi karena ginjal yang tidak berfungsi akibat batu didapatkan hasil histopatologi berupa keganasan sebanyak 9 pasien (9,3\%) yaitu 3 karsinoma sel transisional, 2 karsinoma sel squamosa, 3 karsinoma sel ginjal dan 1 kasus kasinoma sel ginjal yang bersamaan dengan karsinoma sel transisional.

Berdasarkan latar belakang inilah, maka peneliti tertarik ingin mengetahui bagaimana hubungan antara batu saluran kemih bagian atas dengan karsinoma sel ginjal dan karsinoma sel transisional pelvis renalis di dua rumah sakit pendidikan di Provinsi Sumatera Barat.

\section{METODE}

Penelitian ini merupakan studi Case-Control study terhadap data rekam medis pada seluruh pasien yang menderita karsinoma sel ginjal dan karsinoma sel transisional pelvis renalis di RSUP Dr. M Djamil Padang dan RSUD Ahmad Mochtar Bukittinggi pada bulan September - Desember 2018 yang memenuhi kriteria inklusi. Teknik sampling yang digunakan adalah purposive sampling.

Besar sampel minimal dihitung dengan menggunakan rumus sebagai berikut:

$\mathrm{n} 1=\mathrm{n} 2=\{\mathrm{Za} \sqrt{2 P Q}+\mathrm{Z} ß \sqrt{\mathrm{P} 1 \mathrm{Q} 1}+\mathrm{P} 2 \mathrm{Q} 2\}^{2}$

$$
(P 1-P 2)^{2}
$$

Keterangan:

$$
\begin{array}{ll}
\mathrm{n} & =\text { Jumlah sampel minimal } \\
\mathrm{Z} \alpha & =1,64 \text { dengan } \alpha=0,1 \\
\mathrm{ZB} & =\text { Kekuatan penelitian }(80 \%)=0,842
\end{array}
$$

$\mathrm{P} 1=$ Proporsi terpajan pada kasus $=0,31$
$\mathrm{P} 2 \quad=$ Proporsi terpajan pada kontrol $=0,13$

Perhitungan:

$$
\mathrm{n}=\frac{\{1,64 \sqrt{2}(0,23)(0,77)+0,84 \sqrt{ }(0,31)(0,68)+(0,13)(0,87)\}^{2}}{(0,2)^{2}}
$$

$n=25$

Dari perhitungan diatas didapatkan jumlah sampel minimal kasus karsinoma sel ginjal dan karsinoma sel transisional pelvis renalis sebanyak 25 pasien.

Kriteria Inklusi: Secara histopatologis didiagnosa sebagai karsinoma sel ginjal atau karsinoma sel transisional pelvis renalis. Data pasien lengkap yang terdiri atas usia, jenis kelamin, riwayat batu saluran kemih bagian atas dan hasil histopatologis.

Kriteria Eksklusi: Secara histopatologis didiagnosa sebagai karsinoma urothelial varian histologi karsinoma sel squamosa dan adenokarsinoma, sarcoma, embryonic or pediatric tumors, lymphomas dan metastase serta menderita lebih dari satu jenis keganasan

Analisa statistik yang digunakan adalah $\mathrm{Chi}$ Square $\left(\mathrm{X}^{2}\right)$. Hasil penelitian dinyatakan bermakna apabila nilai $p<0,05$. Besarnya faktor resiko terhadap efek dilihat melalui nilai Odds ratio (OR).

\section{HASIL}

Hasil penelitian diperoleh dengan pengumpulan data responden secara retrospektif dari dua rumah sakit pendidikan di Sumatera Barat yakni RSUP Dr. M Djamil Padang periode 2007-2018 dan RSUD Ahmad Mochtar Bukittinggi periode 2012-2018. Data diambil dari divisi urologi, laboratorium Patologi Anatomi, dan catatan rekam medis masing-masing rumah sakit. Pengumpulan sampel dimulai dari hasil histopatologi keganasan ginjal yang didapat dari laboratorium patologi anatomi dan secara retrospektif dilakukan pengukuran terhadap variabel umur, jenis kelamin dan batu saluran kemih bagian atas. Penelitian dilaksanakan pada bulan November hingga Desember 2018. 


\section{Karakteristik responden}

Gambaran distribusi frekuensi data responden dengan karsinoma sel ginjal dan karsinoma sel transisional pelvis renalis yang didapat dari penelitian ini dapat dilihat pada Tabel 1

Tabel 1. Distribusi frekuensi karsinoma sel ginjal dan karsinoma sel transisional pelvis renalis berdasarkan jenis kelamin dan umur

\begin{tabular}{lccccccc}
\hline \multirow{2}{*}{ Variabel } & \multicolumn{2}{c}{ RCC } & \multicolumn{2}{c}{ TCC } & \multicolumn{2}{c}{ Rerata } & \multirow{2}{*}{$\mathbf{p}$} \\
\cline { 2 - 5 } & $\mathbf{f}$ & $\%$ & $\mathbf{f}$ & $\%$ & $\mathbf{R C C}$ & TCC & \\
\hline $\begin{array}{l}\text { Jenis } \\
\text { Kelamin }\end{array}$ & & & & & & & 0.115 \\
Laki - & 15 & 44.12 & 11 & 73.33 & & & \\
laki & & & & & & & \\
& & & & & & & \\
Peremp & 19 & 55.88 & 4 & 26.67 & & & \\
uan & & & & & & & \\
& & & & & & & \\
Umur & & & & & 52.8 & 57.5 & 0.249 \\
& & & & & \pm & \pm & \\
& & & & & 13,79 & 11,31 & \\
$20-29$ & 3 & 8.82 & 0 & 0 & & & \\
$30-39$ & 2 & 5.88 & 1 & 6.67 & & & \\
$40-49$ & 8 & 23.53 & 3 & 20 & & & \\
$50-59$ & 9 & 26.47 & 5 & 33.33 & & & \\
$60-69$ & 8 & 23.53 & 2 & 13.33 & & & \\
$70-79$ & 4 & 11.76 & 4 & 26.67 & & & \\
Jmh & 34 & 100 & 15 & 100 & & & \\
\hline
\end{tabular}

Berdasarkan Tabel 1, didapatkan 34 sampel karsinoma sel ginjal dengan jenis kelamin laki-laki 15 sampel (44,12\%) dan perempuan 19 sampel (55,9\%) dengan rasio $1: 1,3$, nilai $p=0,115$. Hasil ini berbeda dengan data kejadian karsinoma sel ginjal menurut EAU Guidelines 2018 yang mendapatkan rasio 1,5:1. ${ }^{5}$ Hasil ini juga berbeda dengan penelitian di RSCM dan RSKD yang mendapatkan rasio laki-laki dibanding perempuan $3,2: 1^{2}$ Nilai $p>0,05$ menunjukkan bahwa tidak ada hubungan antara jenis kelamin dengan karsinoma sel ginjal pada penelitian ini. Hasil ini berbeda dengan penelitian Rossi et al yang mendapatkan adanya hubungan yang bermakna antara jenis kelamin dengan karsinoma sel ginjal. ${ }^{14}$

Sampel karsinoma sel ginjal yang terbanyak adalah kelompok umur 50-59 tahun berjumlah 9 sampel $(26,47 \%)$ dengan rata-rata umur sampel adalah $52,8 \pm 13,79$, nilai $p=0,249$. Hasil ini berbeda dengan kejadian karsinoma sel ginjal menurut $E A U$ Guidelines 2018 yang mendapatkan kelompok umur terbanyak 60 sampai 70 tahun. ${ }^{5}$ Hasil ini hampir sama dengan penelitian di RSCM dan RSKD dimana didapatkan usia rata-rata 52 tahun. $^{2}$ Nilai $p>0,05$ menunjukkan bahwa tidak ada hubungan antara umur dengan karsinoma sel ginjal pada penelitian ini. Hasil ini berbeda dengan penelitian Rossi dkk yang mendapatkan adanya hubungan yang bermakna antara umur dengan karsinoma sel ginjal. ${ }^{14}$

Berdasarkan Tabel 1, didapatkan 15 sampel karsinoma sel transisional pelvis renalis yang dikumpulkan, didapat jumlah sampel dengan jenis kelamin laki-laki 11 sampel $(73,3 \%)$ dan perempuan 4 sampel $(26,67 \%)$ dengan rasio $2,75: 1$, nilai $p=0,115$. Hasil ini hampir sama dengan rasio kejadian karsinoma sel transisional di seluruh dunia menurut EAU Guidelines 2017 yang mendapatkan rasio 3:1. ${ }^{6}$ Hasil ini juga hampir sama dengan penelitian Zulfiqar et al yang mendapatkan rasio $2: 1 .^{8}$ Nilai $p>0,05$ menunjukkan bahwa tidak ada hubungan antara jenis kelamin dengan karsinoma sel transisional pelvis renalis pada penelitian ini. Hasil ini berbeda dengan dengan Population-based and multi-institutional studies yang menunjukkan adanya hubungan yang bermakna antara jenis kelamin dengan karsinoma sel transisional. ${ }^{15}$

Sampel terbanyak karsinoma sel transisional pelvis renalis adalah kelompok umur 50-59 tahun yang berjumlah 5 sampel (33,33\%) dengan rata-rata umur sampel adalah $57,5 \pm 11,31$, nilai $p=0,249$. Hasil ini berbeda dengan EAU Guidelines 2017 yang mendapatkan kelompok umur terbanyak 70-90 tahun. ${ }^{6}$ Hasil ini hampir sama dengan penelitian Zulfiqar et al yang mendapatkan umur rerata 53,5 tahun. ${ }^{8}$ Nilai p>0,05 menunjukkan bahwa tidak ada hubungan antara umur dengan karsinoma sel transisional pelvis renalis pada penelitian ini. Hal ini berbeda dengan penelitian yang didapat wang et all yang menunjukkan adanya hubungan yang bermakna antara umur dengan karsinoma sel transisional. ${ }^{16}$

\section{Hubungan antara batu saluran kemih bagian atas dengan karsinoma sel ginjal dan karsinoma transisional pelvis renalis}

Gambaran distribusi frekuensi jenis histopatologi keganasan ginjal yang didapat dari penelitian ini dapat dilihat pada Tabel 2. 
Tabel 2. Distribusi frekuensi jenis histopatologis keganasan ginjal

\begin{tabular}{|c|c|c|c|}
\hline No & Jenis tumor & $\mathbf{f}$ & $\%$ \\
\hline 1. & Renal cel carcinoma & 34 & 50 \\
\hline \multirow[t]{5}{*}{2.} & Urothelium based & & \\
\hline & - Trantitional cel & 15 & 22,06 \\
\hline & carcinoma & 10 & 14,71 \\
\hline & $\begin{array}{l}\text { - Squamous cell } \\
\text { carcinoma }\end{array}$ & 4 & 5,88 \\
\hline & - Adenocarsinoma & & \\
\hline 3. & Sarcoma & 2 & 2,94 \\
\hline 4. & Metastasis & 1 & 1,47 \\
\hline 5. & $\mathrm{RCC}+\mathrm{TCC}$ & 2 & 2,94 \\
\hline Jumlah & & 68 & 100 \\
\hline
\end{tabular}

Berdasarkan Tabel 2, terlihat 68 hasil histopatologi keganasan ginjal yang didapatkan terdiri dari: jenis histopatologi karsinoma sel ginjal berjumlah 34 kasus (50\%), karsinoma sel transisional 15 kasus $(22,06 \%)$, karsinoma sel squamosa 10 kasus $(14,71 \%)$, adenokarsinoma 4 kasus $(5,88 \%)$, sarkoma 2 kasus (2,94\%), metastasis 1 kasus $(1,47 \%)$, karsinoma sel ginjal bersamaan dengan karsinoma sel transisional 2 kasus (2,94\%). Hasil ini sesuai hamper sama dengan data dari dua rumah sakit tersier di Jakarta, Indonesia, rumah sakit Cipto Mangunkusumo dan Pusat Kanker Dharmais tahun 1995 hingga 2007 (13 tahun) didapatkan 144 kasus karsinoma sel ginjal berjumlah 77 kasus (53,5\%). ${ }^{4}$ Jumlah kasus karsinoma sel transisional pelvis renalis yang didapatkan pada penelitian ini sebanyak 15 kasus atau $20,97 \%$ dari seluruh keganasan ginjal. Hasil ini hampir sama dengan survey epidemiologi sebelumnya yang mendapatkan karsinoma sel transisional dinegaranegara berkembang mempunyai prevalensi antara $4 \%$ hingga $20 \%{ }^{17}$

Tabel 3. Hubungan batu saluran kemih bagian atas dengan karsinoma sel ginjal

\begin{tabular}{|c|c|c|c|c|c|c|c|}
\hline \multirow{3}{*}{ Batu } & \multicolumn{3}{|c|}{ RCC } & & \multirow{2}{*}{\multicolumn{2}{|c|}{ Total }} & \multirow{3}{*}{$\mathbf{P}$} \\
\hline & \multicolumn{2}{|c|}{ Tidak ada } & \multicolumn{2}{|l|}{ ada } & & & \\
\hline & $f$ & $\%$ & $f$ & $\%$ & $f$ & $\%$ & \\
\hline Tidak & 20 & 76,9 & 3 & 37,5 & 23 & 67,6 & 0,07 \\
\hline Ada & 6 & 23,1 & 5 & 62,5 & 11 & 32,4 & \\
\hline Jmh & 26 & 100 & 8 & 100 & 34 & $100 \%$ & \\
\hline
\end{tabular}

Berdasarkan Tabel 3 didapatkan persentase yang ada batu lebih tinggi pada karsinoma sel ginjal dibandingkan dengan yang tidak karsinoma sel ginjal yaitu $62,5 \%$ : 23,1\%. Secara statistik perbedaan tersebut tidak bermakna $(P>0,05)$. Peluang untuk timbulnya karsinoma sel ginjal sebesar 5,6 kali pada yang ada batu dibandingkan dengan yang tidak ada.

Hasil ini sama dengan penelitian Chow et al yang melaporkan bahwa batu ginjal tidak meningkatkan resiko karsinoma sel ginjal. ${ }^{18}$ Hasil ini berbeda dengan penelitian yang didapatkan oleh Chung et al yang mendapatkan adanya hubungan yang bermakna antara batu saluran kemih bagian atas dengan karsinoma sel ginjal dan batu saluran kemih bagian atas meningkatkan resiko karsinoma sel ginjal 2,76 kali. $^{12}$ Hasil ini juga berbeda dengan penelitian yang didapatkan oleh Cheungpasitporn et al yang menemukan adanya hubungan yang bermakna antara batu saluran kemih bagian atas dengan karsinoma sel ginjal dengan karsinoma sel ginjal dan batu saluran kemih bagian atas meningkatkan resiko karsinoma sel ginjal 1,76 kali. $^{9}$

Tabel 4. Hubungan batu saluran kemih bagian atas dengan karsinoma sel transisional pelvis renalis

\begin{tabular}{|c|c|c|c|c|c|c|c|c|c|c|}
\hline \multirow{3}{*}{ Batu } & \multicolumn{6}{|c|}{ TCC } & \multirow{2}{*}{\multicolumn{3}{|c|}{ Total }} & \multirow{3}{*}{$\mathbf{p}$} \\
\hline & \multicolumn{3}{|c|}{ Tidak ada } & \multicolumn{3}{|c|}{ Ada } & & & & \\
\hline & & $f$ & $\%$ & & $f$ & $\%$ & & & $\%$ & \\
\hline Tidak & & 6 & 75,0 & & 2 & 28,6 & & 8 & 53,3 & 0.13 \\
\hline Ada & & 2 & 25,0 & & 5 & 71,4 & & 7 & 46,7 & \\
\hline $\mathrm{Jmh}$ & 8 & 10 & & 8 & 100 & & 15 & 10 & & \\
\hline
\end{tabular}

Berdasarkan Tabel 4 didapatkan persentase yang ada batu lebih tinggi pada karsinoma sel transisional pelvis renalis dibandingkan dengan yang tidak karsinoma sel transisional pelvis renalis yaitu $71,4 \%$ : 25\%. Secara statistik perbedaan tersebut tidak bermakna $(P>0,05)$. Peluang untuk timbulnya karsinoma sel transisional pelvis renalis sebesar 7,5 kali pada yang ada batu dibandingkan dengan yang tidak ada. Hasil ini berbeda dengan penelitian Zulfiqar dkk yang mendapatkan adanya hubungan yang bermakna antara batu dengan karsinoma sel transisional pelvis renalis. ${ }^{8}$ Hasil ini juga berbeda 
dengan penelitian yang didapatkan oleh Cheungpasitporn et al yang menemukan adanya hubungan yang bermakna antara batu saluran kemih bagian atas dengan karsinoma sel transisional pelvis renalis dan batu saluran kemih bagian atas meningkatkan resiko 2,14 kali. $^{9}$ Hasil ini berbeda dengan penelitian yang didapatkan oleh Chung et al yang mendapatkan adanya hubungan yang bermakna antara batu saluran kemih bagian atas dengan karsinoma sel transisional pelvis renalis dan batu saluran kemih bagian atas meningkatkan resiko karsinoma sel ginjal 3,96 kali. $^{12}$

\section{SIMPULAN}

Tidak terdapat hubungan yang bermakna antara batu saluran kemih bagian atas dengan karsinoma sel ginjal. Batu saluran kemih bagian atas meningkatkan resiko karsinoma sel ginjal 5,6 kali.

Tidak terdapat hubungan yang bermakna antara batu saluran kemih bagian atas dengan karsinoma sel transisional pelvis renalis. Batu saluran kemih bagian atas meningkatkan resiko karsinoma sel transisional pelvis renalis 7,5 kali.

\section{DAFTAR PUSTAKA}

1. Purnomo BB. Dasar-dasar Urologi. Edisi ke-2. Jakarta: CV. Sagung Seto; 2003.

2. Umbas R, Hardjowijoto S, Safriadi F, Mochtar C Djatisoesanto $\mathrm{W}$, Soedarso $\mathrm{M}$, et al. Panduan penanganan kanker ginjal. Jakarta: Ikatan Ahli Urologi Indonesia; 2012.

3. Ferlay J, Soerjomataram I, Ervik $\mathrm{M}$, et al. GLOBOCAN 2012 v1.0, Cancer Incidence and Mortality Worldwide: IARC Cancer Base No.11 [Internet]. Lyon, France: International Agency for Research on Cancer, 2013 (diunduh 27 Januari 2015). Tersedia dari: http://globocan.iarc.fr

4. Hamiseno D, Mochtar CA, Umbas R. Current systemic therapy in metastatic renal cell carcinoma. Indones J Cancer. 2011;5:105-12.

5. Ljungberg B, Albiges L, Bensalah K, Bex A, Giles RHM, Hora, et al. EAU Guidelines on Renal Cell Carcinoma. European Association of Urology; 2018

6. Roupre^t M, Babjuk M, Compe'rat E, Zigeuner R, Sylvester RJ, Burger $\mathrm{M}$, et al. European
Association of Urology Guidelines on Upper Urinary Tract Urothelial Carcinoma: 2017 Update. European Urology. 2018;73:111-22.

7. Woodford R, Ranasinghe W, Aw HC, Sengupta S, Persad R. Trends in incidence and survival for upper tract urothelial cancer (UTUC) in the state of Victoria-Australia. BJU Int. 2016;117: Suppl 4:45-9.

8. Zulfiqar $\mathrm{Y}$, Umbas R, Mochtar CA, Santoso RB, Hamid ARA. Karsinoma pelvis renis dan ureter di Jakarta: karakteristik dan faktor resiko. Indonesian Journal of Cancer. 2010;4:61-5.

9. Cheungpasitporn W, Thongprayoon C. O'Corragain O, Edmond P, Ungprasert, Kittanamongkolchai $\mathrm{W}$, et al. The risk of kidney cancer in patients with kidney stones: a systematic review and meta-analysis. Q J Med. 2015;108:20512.

10.Liu Y, Chen Y, Liao B, Luo D, Wang K, Li H, Zeng G. Epidemiology of urolithiasis in Asia Asian Journal of Urology 2018; xx;1-10.

11.Zamzami Z. Penatalaksanaan terkini batu saluran kencing di RSUD Arifin Achmad Pekanbaru, Indonesia: Current management of urinary stones in Arifin Achmad Hospital Pekanbaru, Indonesia. Jurnal Kesehatan Melayu. 2018;1:60-6.

12.Chung SD, Liu SP, Lin HC. A population-based study on the association between urinary calculi and kidney cancer. CUAJ. 2013 Dec;7(11-12):71621.

13.Zengin K, Tanik S, Sener N, Albayrak S, Ekici M, Bozkurt I, et al. Incidence of renal carcinoma in non-functioning kidney due to renal pelvic stone disease. Molecular and Clinical Oncology. 2015;3:941-3

14.Rossi SH, Klatte T, Smith JU, Stewart GD. Epidemiology and screening for renal cancer. World Journal of Urology:2018.

15.Shariat SF, Matin S, Stenzl A. Upper tract urothelial carcinoma. A joint SIU-ICUD International Consultation Montréal: Société Internationale d'Urologie (SIU);2013.

16.Wang LJ, Chou WC, Pang ST, Yang CW, Chuang $\mathrm{KC}$, Chang $\mathrm{YH}$, et al. Risk Stratification of upper urinary tract urothelial carcinoma patients for 
survival prediction: a simple summation scoring method. Journal of Cancer. 2018;9:2284-94.

17.Sun LM, Lin CL, Chang YJ, Liang JA, Liu SH, Sung $\mathrm{FC}$, et al. Urinary tract stone raises subsequent risk for urinary tract cancer: a population-based cohort study. BJU Int. 2013;112:1150-5.
18. Chow W, Lindblad P, Gridley G, Nyrén O, Mclaughlin J, Linet $\mathrm{M}$, et al. Risk of urinary tract cancers following kidney or ureter stones. Journal of the National Cancer Institute. 1997; 89 (19): 1453-6. 